\section{疲労損傷評価のための暴風の累 積作用時間の簡易評価方法}

SIMPLE METHOD FOR EVALUATING
CUMULATIVE TIME OF WIND SPEED
FOR ESTIMATING FATIGUE DAMAGE

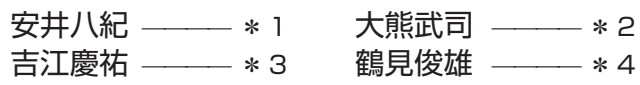

キーワード :

累積疲労損傷，累積作用時間，経験的再現期間，

台風シミュレーション，等価継続時間

Keywords:

Cumulative fatigue damage, Cumulative time, Empirical return period, Typhoon simulation, Equivalent duration time

$\begin{array}{ll}\text { Hachinori YASUI }-* 1 & \text { Takeshi OHKUMA - } * 2 \\ \text { Keisuke YOSHIE }-* 3 & \text { Toshio TSURUMI- } * 4\end{array}$

Increasing number of high-rise buildings are being equipped with energy absorption devices of elasto-plastic materials. It is important to ensure the safety of these devices to not only under design wind speed but also under cumulative fatigue damage due to wind loading during use. In determining cumulative damage, it is necessary to evaluate the cumulative time of wind speed in a period and the wind response to each wind speed. This paper presents a simple method for evaluating the cumulative time of wind speed in a period and its effectiveness.

\section{1. はじめに}

近年，材料の塑性変形によるエネルギー吸収能力を利用した部材 を超高層建築物に適用する事例が増加してきている。このような塑 性変形を伴う部材の風荷重に対する安全性は, 設計風速に対する安 全性の他, 累積疲労損傷度も重要な照査項目である。この風に対寸 る累積疲労損傷度を評価するためには，対象とする期間に渡る風速 の累積作用時間の算定，各風速における応答振幅の算定および疲労 曲線が必要となる。また，この算定する期間には，ダンパーのよう に取換可能な部材を対象とした期間，積層ゴムのように取換が困難 な部材を対象とした期間が考えられるが，現状いずれも法的に特定 されるものではない。ここでは，照査の対象期間という意味で照査 期間と呼ぶこととする。

照查期間における風速の累積作用時間の算定方法としては幾つか の方法が提案 2),3),4) されているが, 近年では, その暴風の発生要因を 台風と非台風に区分し，前者については Monte Carlo 法に基づく台 風シミュレーション(以降, 台風シミュレーションと呼ぶ), 後者に ついては近隣の気象官署の観測データを Weibull 分布に当てはめ, その結果から算定する方法がしばしば用いられている ${ }^{5)}$.

しかしながら，台風シミュレーションを用いるためには，台風デ 一タの確率統計的な分析とこの結果の運用が必要となる. また, 得 られる結果が「建築物荷重指針・同解説(2004) 日本建築学会」(以 降, 荷重指針と呼ぶ)等における設計風速に対し, どのような位置づ けとなるかが解り難いといったこともある.

本報告は、文献 2) 4)の考え方を参考に, 荷重指針から暴風の累 積作用時間を簡易に評価する方法を提案し，その有効性を示すもの
である。

\section{2. 暴風の最大風速の簡易評価方法}

\section{1 評価方法の概要}

荷重指針には, 再現期間 100 年と 500 年の平均風速(それぞれ, $U_{0}$, $\left.U_{500}\right)$ が風速マップとして示されており,さらに, これら以外の再現 期間 $r$ 年に対応する最大風速 $U_{r}$ については, 再現期間換算係数 $k_{r w}$ を用いて以下のように算定できるとしている.

$$
\begin{aligned}
& U_{r}=U_{0} k_{r w} \\
& k_{r w}=0.63\left(\lambda_{U}-1\right) \ln r-2.9 \lambda_{U}+3.9 \\
& \lambda_{U}=U_{500} / U_{0}
\end{aligned}
$$

これらの式から，式(1)は以下のように表わすことができる.

$$
U_{r}=0.63\left(U_{500}-U_{0}\right) \ln r-2.9\left(U_{500}-U_{0}\right)+U_{0}
$$

式(2)の再現期間換算係数 $k_{r w}$ は, 年最大風速の漸近極值分布とし て下式(5)の Gumbel 分布を仮定し, 再現期間 100 年および 500 年の 風速がそれぞれ $U_{0}$ および $U_{500}$ に一致するように近似したものであ る.

$$
\begin{array}{ll}
U_{i}=b-\left\{\ln \left(-\ln F_{i}\right)\right\} / a & (i=1, \cdots, N) \\
F_{i}=1-P_{i} & (i=1, \cdots, N) \\
r_{i}=1 / P_{i} & (i=1, \cdots, N)
\end{array}
$$

ここに, $U_{i}$ は観測期間あるいは照査期間 $N$ 年における $i$ 番目に 大きな年最大風速， $a$ および $b$ は係数， $F_{i}$ は経験的非超過確率， $P_{i}$ は経験的超過確率， $r_{i}$ は経験的再現期間である.

疲労損傷評価においては, 年最大の暴風だけでなく, 年 2 位以下 の暴風も考慮する必要があると考えられるため，荷重指針の再現期

本稿は 2012 年日本建築学会関東支部にて発表した文献 1) を加筆したものである。 (株)泉創建エンジニアリング都市環境技術研究所 副所長・博士（工学） ( ( 299-0268 千葉県袖ケ浦市南袖 51)

神奈川大学工学研究所 客員教授. 工博

(株)日建設計 構造設計部長・博士（工学）

(株)泉創建エンジニアリング都市環境技術研究所

General Manager, Urban Environment Research Center, Izumi Sohken Engineering Co., Ltd., Dr. Eng.

Prof., Kanagawa Univ., Dr. Eng.

General Manager, Structural Engineering Dept., Nikken Sekkei Ltd., Dr. Eng.

Manager, Urban Environment Research Center, Izumi Sohken Engineering Co., Ltd. 
間換算係数の定め方を参考にしつつ, 修正 Jansen \& Frank 法(以降, MJF 法と呼ぶ)により経験的超過確率を評価することとし, 式(6), (7) の代わりに以下の式(8)〜(11)を用いる.

$$
\begin{array}{ll}
F_{i}=\left(1-P_{i}\right)^{m} & \left(i=1, \cdots, N_{S}\right) \\
P_{i}=(i-0.5) / m N & \left(i=1, \cdots, N_{S}\right) \\
r_{i}=1 / m P_{i} & \left(i=1, \cdots, N_{S}\right) \\
m=N_{S} / N &
\end{array}
$$

ここに, $N_{S}$ は $N$ 年間の全暴風数, $m$ は年平均の暴風数であり, 式(5)に式(8)を代入すれば以下のように表わされる.

$$
U_{i}=b-\left[\ln \left\{-m \ln \left(1-P_{i}\right)\right\}\right] / a
$$

式(12)によって算定される再現期間 100 年および 500 年の風速が それぞれ $U_{0}$ および $U_{500}$ に一致する条件を与え，荷重指針と同様の 形式に書き改めると以下のように表わされる.

$$
\begin{aligned}
& U_{i}=\left(U_{500}-U_{0}\right) C_{i} \ln r_{i} / A-\left(U_{500}-U_{0}\right) B / A+U_{0} \\
& A=\ln \{\ln (1-1 / 500 m) / \ln (1-1 / 100 m)\} \\
& B=\ln \{-m \ln (1-1 / 100 m)\} \\
& C_{i}=\ln \left\{-m \ln \left(1-1 / m r_{i}\right)\right\} / \ln r_{i}
\end{aligned}
$$

再現期間を 10 年 5000 年, 年平均の暴風数 $m$ を $1 \sim 10$ として, 式(13)中の $C_{i} / A$ および $B / A$ を算定すると以下のような值となり, 同 式が荷重指針の式(4)と殆ど差異のない式であることがわかる.

\section{$C_{i} / A \approx 0.61 \sim 0.62, \quad B / A \approx 2.9$}

したがって, 年平均の暴風数 $m$ が自明であれば, 照査期間中の $i$ 番 目に大きな最大風速 $U_{i}$ の再現期間 $r_{i}$ は式(10)で算定でき, その最大 風速 $U_{i}$ は荷重指針による式(4)で得られることになる。

\section{2 年平均の台風数 $m_{T}$}

年平均の暴風数について検討するに当たり, まず, 台風に限定し て検討する．ここでは，台風シミュレーションを用いて年平均の台 風数 $m_{T}$ を算定する. 台風シミュレーションは以下のような条件の もとに行っている．なお，ここで観測記録ではなく台風シミュレー ションを用いたのは, 本手法が文献 6)において吟味されていること に加え, 後にシミュレーション結果を暴風の時間変化のモデル化へ 利用すること, さらに簡易評価方法との比較を行うためである.

(1) 荷重指針と同質のシミュレーション結果が得られることを 確認するため, 荷重指針と同様に 5000 年の台風シミュレー ション 6) を実施する.ただし, 台風シミュレーション結果の ばらつきについて検討するため, この 5000 年の台風シミュ レーションを 10 組行う。

（2) 概ね日本全国に渡っての情報を得るため，台風シミュレーシ ヨンの対象地点は, 表 1 および図 1 に示す気象官署 29 地点 とする. なお, 本報告においては, 伊豆諸島, 薩南諸島, 大 東諸島, 先島諸島および小笠原諸島を検討対象外としている. これは，この地域の暴風の風速の時間変化が，ここで対象と 寸る九州以北の地域と異なると考えられるためである. 従っ て, これらの検討対象外の地域については, ここで提案する 暴風の累積作用時間の簡易評価方法においても適用範囲外 である.

(3) 再現期間 100 年の風速が基本風速 $U_{0}$ と一致するように上空 風に対する地上風の風速比を決定する. ただし, 基本風速 $U_{0}$ マップからの風速の読み值は $2 \mathrm{~m} / \mathrm{s}$ 刻みとする.

(4) 10 分平均風速の変動係数を $0.10^{6,7)}$ とすることで, 平均化時
間 10 分の風速の時刻歴を得る.

(5) 中心気圧が一次的にも $980 \mathrm{hPa}$ 以下に下がった台風で, その 中心が検討地点から $500 \mathrm{~km}$ 以内に位置した台風 ${ }^{6), 8), 99}$ の数を 台風数 $m_{T}$ とする.

台風数 $m_{T}$ と共に，荷重指針における $U_{500}$ と台風シミュレーショ ンによる再現期間 500 年の風速 $U_{500 S}$ を比較して表 1 , 図 1 に示す. 荷重指針における基本風速 $U_{0}$ および $U_{500}$ 共に $2 \mathrm{~m} / \mathrm{s}$ 刻みで読み取 っていることを考慮すると, 表 1 に示寸台風シミュレーションによ る再現期間 500 年の風速 $U_{500 s}$ は荷重指針における $U_{500}$ に良く対応 していると言え, 荷重指針の風速マップ作成時に用いられた台風シ ミュレーションと同質の結果が得られていると考えられる.

年平均台風数 $m_{T}$ は, 東京より西側の太平洋側では $2.3 \sim 1.8$ 程度 の值, 北関東, 中部地方の内陸部, 福井県より西側の日本海側と瀬 戸内海地方では 1.7 前後の值, 石川県・新潟県および福島県・宮城 県では $1.5 \sim 1.2$ 程度の值, 秋田県および岩手県以北では 1 以下の值 である. 寸なわち, 本報告で対象とする九州以北における年平均台 風数 $m_{T}$ は $0.5 \sim 2.3$ の範囲の值である.

表 1 再現期間 500 年の風速と年平均台風数 $\boldsymbol{m}_{T}$

\begin{tabular}{c|c|c|c|c|c|c|c|c|c}
\hline 官署 & $U_{0}$ & $U_{500}$ & $U_{5005}$ & $m_{T}$ & 官署 & $U_{0}$ & $U_{500}$ & $U_{500 S}$ & $m_{T}$ \\
\hline 札幌 & 32 & 36 & 36.5 & 0.53 & 名古屋 & 34 & 38 & 37.7 & 1.94 \\
\hline 青森 & 32 & 36 & 36.6 & 0.75 & 大阪 & 36 & 40 & 39.8 & 1.96 \\
\hline 秋田 & 36 & 40 & 41.1 & 0.90 & 岡山 & 30 & 34 & 33.3 & 1.79 \\
\hline 宫古 & 32 & 36 & 36.1 & 0.96 & 広島 & 30 & 34 & 33.0 & 1.69 \\
\hline 酒田 & 36 & 40 & 40.7 & 1.06 & 和歌山 & 40 & 42 & 44.2 & 2.05 \\
\hline 仙台 & 32 & 36 & 35.7 & 1.23 & 德島 & 40 & 44 & 44.0 & 2.03 \\
\hline 新渴 & 38 & 42 & 42.6 & 1.28 & 福岡 & 34 & 38 & 37.9 & 1.59 \\
\hline 小名浜 & 34 & 38 & 38.1 & 1.59 & 高知 & 40 & 44 & 44.2 & 2.05 \\
\hline 金沢 & 34 & 38 & 37.9 & 1.51 & 潮岬 & 40 & 42 & 43.6 & 2.35 \\
\hline 前橋 & 32 & 36 & 35.9 & 1.70 & 大分 & 32 & 36 & 35.3 & 1.87 \\
\hline 水戸 & 32 & 36 & 35.4 & 1.75 & 熊本 & 34 & 36 & 37.7 & 1.83 \\
\hline 松本 & 30 & 34 & 33.7 & 1.69 & 長崎 & 38 & 42 & 42.1 & 1.71 \\
\hline 東京 & 38 & 42 & 42.4 & 1.94 & 宮崎 & 36 & 40 & 39.7 & 2.18 \\
\hline 敦賀 & 34 & 38 & 37.9 & 1.73 & 鹿児島 & 42 & 46 & 46.0 & 2.13 \\
\hline 鳥取 & 32 & 36 & 35.6 & 1.61 & & & & & \\
\hline & & & & & \\
\hline
\end{tabular}

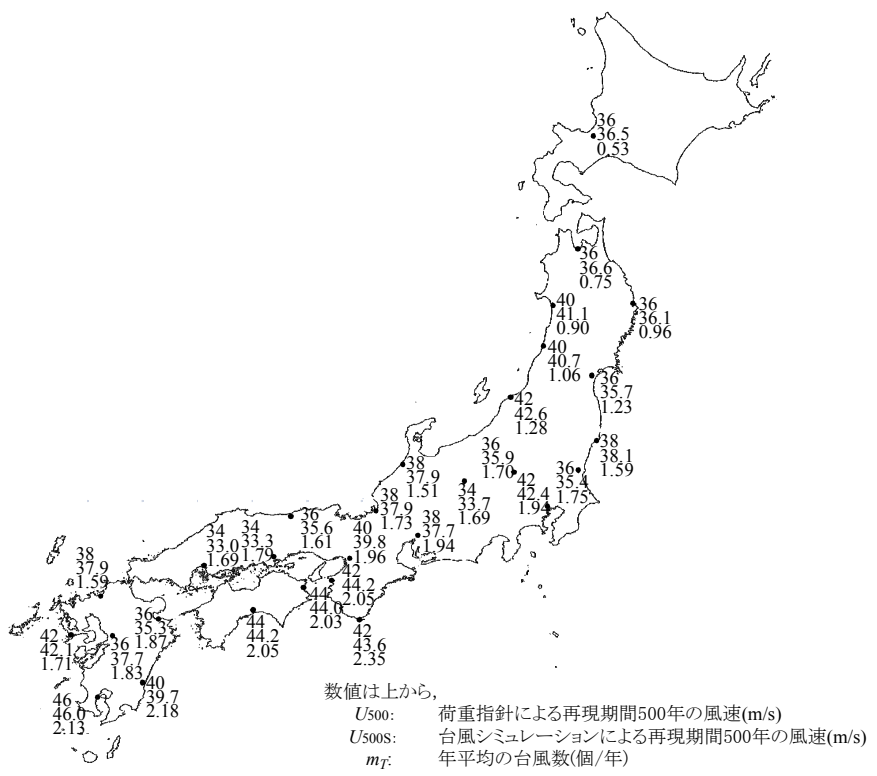

図 1 再現期間 500 年の風速と年平均台風数 $\boldsymbol{m}_{T}$ 
鹿児島, 名古屋, 水戸および仙台を事例に, 照査期間 $N$ を 250 年 とした場合の再現期間 $r_{i}$ と最大風速 $U_{i}$ の関係について, 荷重指針と 台風シミュレーション結果を比較して図 2 に示寸。なお，台風シミ ユレーションについては, 各再現期間に対応する 10 個の最大風速の 内の最大值および最小值ならびに平均值を併記している.

同図に示すように，荷重指針による最大風速は台風シミュレーシ ヨンによる最大風速と再現期間 10 年を超えるような領域では良く 対応する. 再現期間 10 年以下での差異は, 指針式により算定される 暴風には台風以外も含まれていること, 同式が再現期間 100 年と 500 年の值を通る近似式であることがその要因である.
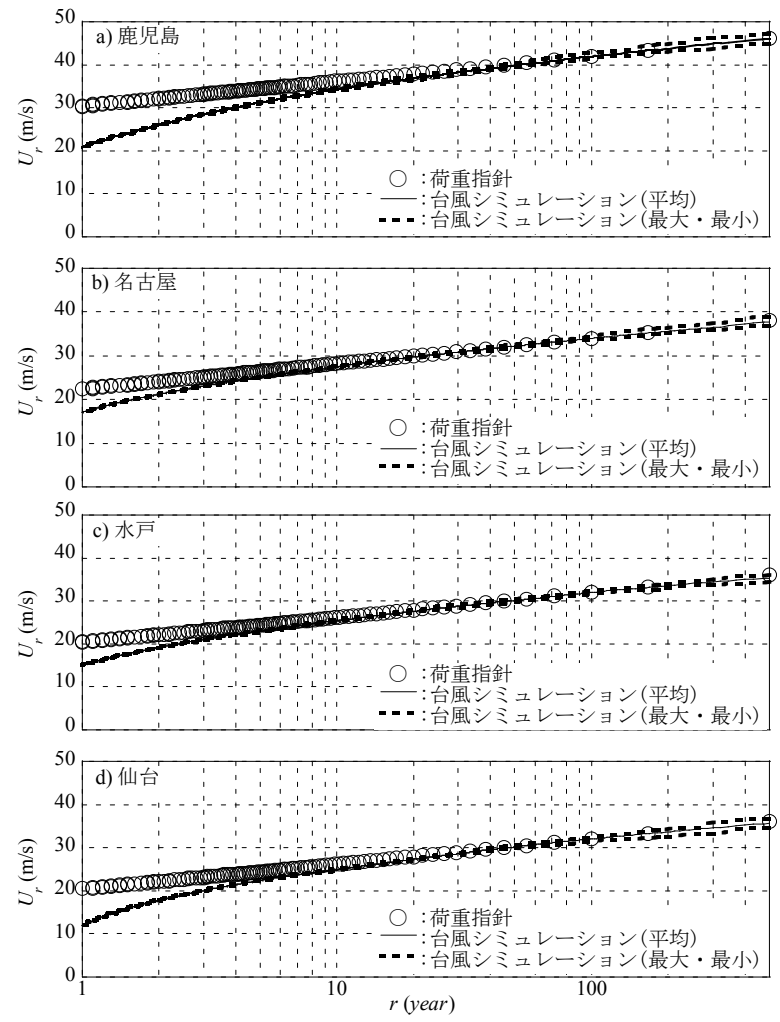

図 2 再現期間と最大風速の算定法による差異

\section{3 年平均の暴風数 $m$}

ここでは, 年平均の暴風数 $m$ が経験的再現期間等にどの様に影響 を与えるかについて検討する。

式(10)に式(9)を代入して整理すると，MJF 法による経験的再現期 間は以下のように表わされる。

$$
r_{i}=N /(i-0.5) \quad\left(i=1, \cdots, N_{S}\right)
$$

この式は， $m \geq 1$ であれば $N_{S} \geq N$ となるので, 上位 $N$ 個の経験的 再現期間は暴風数 $m$ に依存しないことを示している．さらに，筆者 等は荷重指針式(4)が暴風数 $m$ を考慮した式(12)あるいは式(13)と殆 ど差異がないことを先に示した。これらを合せて考慮すると， $m \geq 1$ の場合には，上位 $N$ 個以内であれば，式(17) と荷重指針を用いて算 定される $i$ 番に大きな最大風速は年平均の暴風数 $m$ に依存しないこ とになる．前述したように九州以北における年平均台風数は 0.5 2.3 であり，冬季から春季にかけての低気圧等を考慮すると 1 を超 えるような值であるとから, 上位 $N$ 個の最大風速は年平均の暴風数 $m$ に依存しないと考えられる.
照查期間 $N$ 年における 1 番目および $N$ 番目に大きな最大風速の 再現期間は，式(17)の MJF 法において $m \geq 1$ であれば，それぞれ $2 N$ 年および約 1 年である. 式(17)の経験的再現期間を用いて式(4)より 算定される $N$ 番目に大きな最大風速は，基本風速に対して $6 \mathrm{~m} / \mathrm{s} \sim$ $12 \mathrm{~m} / \mathrm{s}$ 低く，基本風速の最も小さい $30 \mathrm{~m} / \mathrm{s}$ 場合で $24 \mathrm{~m} / \mathrm{s} \sim 18 \mathrm{~m} / \mathrm{s}$ とな る. 松井等 ${ }^{10)}$ が提案する等価継続時間は，その強風イベントの最大 風速が継続した場合に，その強風のイベントによる総エネルギーや 累積疲労損傷と等価になるような継続時間と定義している。また， 疲労損傷については, 疲労延性指数を $m_{s}$ ( $2 \sim 3$ 程度の值), 風速に対 する応答変位の変動成分の増減を表わすべき数を $n_{d}(2 \sim 3$ 程度の 值)とすると, 等価継続時間は風速の $m_{s} n_{d}(4 \sim 9)$ 乗に比例すると見積 もられる，松井等に倣って $m_{s} n_{d}=9$ とすると, 基本風速に対する再 現期間約 1 年の風速の等価継続時間は $16 \% \sim 1 \%$ と小さく, 上位 $N$ 個 の最大風速 $U_{r}$ がある程度精度良く予測できれば，累積疲労損傷度 評価には十分と考えられる.

\section{3. 暴風の時間変化の算定法}

疲労損傷評価においては，暴風の最大風速の予測だけではなく， 風速の時間変化の情報も必要となる。この情報については荷重指針 では得られないため, 先に求めた台風シミュレーションの結果から, 風速の時間変化をモデル化する，なお，荷重指針における最大風速 は台風に限定されたものではないが，非台風の時間変化も台風と同 様であると見なすこととする.

暴風の時間変化のモデル化手順を以下に示す.

(1) 最大風速が再現期間 1 年 500 年の暴風のみを対象とする. これは，照查期間 $N$ 年において $N$ 番目に大きな最大風速の 再現期間が概放 1 年に相当すること, 建築基準法施行令第 81 条の 2 に該当する建築物において安全性の検証が求められる

「極めて稀に発生する暴風」の再現期間が概ね 500 年に相当 することを考虑したものである。

(2) 暴風の継続時間は，一次的にも $980 \mathrm{hPa}$ 以下に下がった台風 で，その中心が検討地点から $500 \mathrm{~km}$ 以内 ${ }^{6,8), 9)}$ である時間と 24 時間の内の短い方とする.

(3) 台風シミュレーションで得られた各暴風の 10 分毎の風速を 降順に並び替え ${ }^{3), 4}$, 並び替え後の最大風速の時刻 $t$ (単 位:hour)を 0 として降順位に時刻を定義する.

(4) 時刻 $t$ 毎に対象の全暴風の風速を合計し, 時刻 $t=0$ の風速の 合計值に対する比 $r_{U}(t)$ を求める.

(5) 風速比 $r_{U}(t)$ の高い 0 時間から 12 時間を式(18)で，24 時間全 体を式(19)によって回帰する.

$r_{U}(t)=\left(1+C_{1} t\right) / \exp \left(C_{2} t^{0.70}\right)$

$r_{U}(t)=\left(1+C_{3} t^{2.2}\right) / \exp \left(C_{4} t^{1.2}\right)$

なお，式(18)および式(19)において時間 $t$ のべき指数として採用し ている 1.0，0.70，2.2，1.2 は，これらの指数も回帰パラメータとし て近似した結果，その值のばらつきが小さかったことから，より簡 便な式とするために平均的な值を採用したものである.

図 1 に示した 29 地点についての算定結果の内, 16 地点の結果を 図 3 に示寸。なお, 図中では○印が台風シミュレーション結果, 破 線が式(18)による回帰曲線，実線が式(19)による回帰曲線である.

同図に示寸ように，式(18)による回帰曲線は台風シミュレーショ 
ン結果と風速比の高い $0 \sim 12$ 時間まででは良く一致しており，12 時 間以降については安全側に評価されている。 また, 式(19)による回 帰曲線は 24 時間全体に渡って台風シミュレーション結果と良く一 致している.
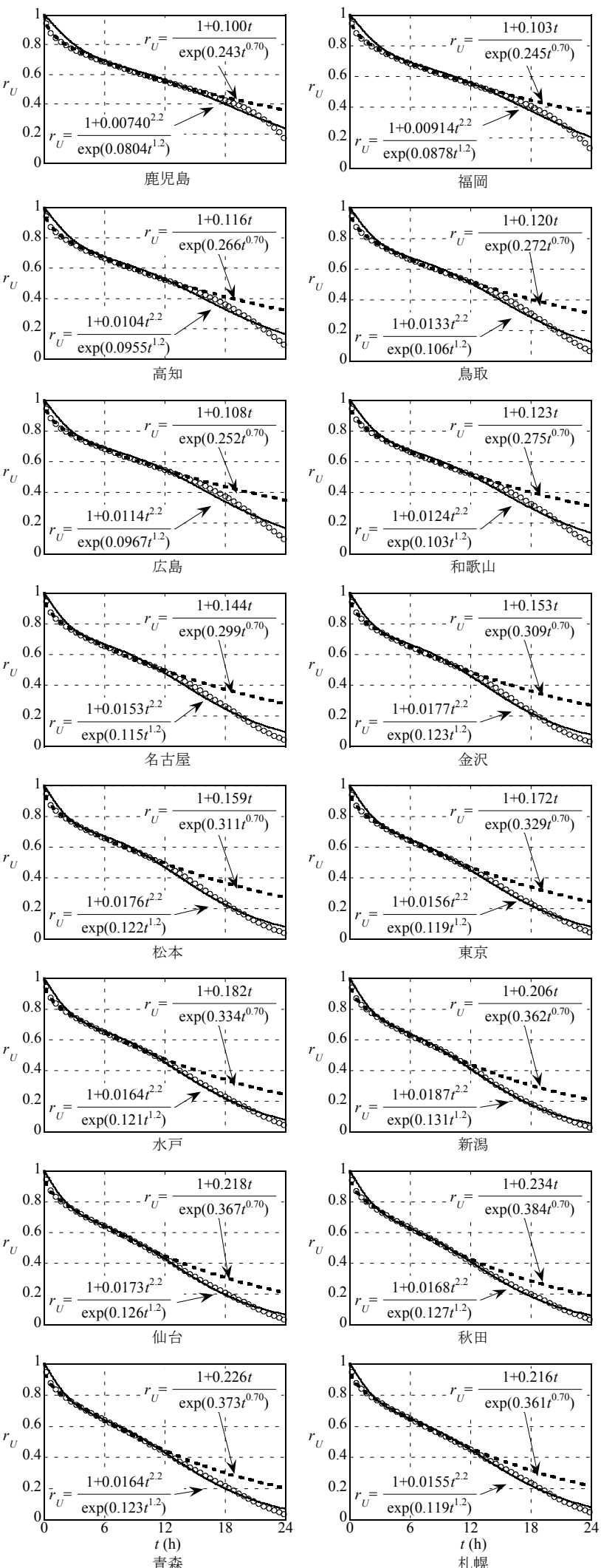

図 3 風速比の時閒変化
因みにこここに示した簡易評価方法と成原等 ${ }^{3)}$ の方法との違いは, 以下の通りである.

(1) 本法ではその基となった台風シミュレーションに 10 分平均 風速の変動係数を考慮し, 平均化時間 10 分の風速を評価し ていることに対して, 成原等 ${ }^{3)}$ の方法では変動係数を考慮し ていない，この違いは，時間に対する風速比でみると, 前者 に比較して後者は高めの值を与えることになる．

(2) 本法が式(18)および式(19)に示すように風速比一時間の関係 をモデル化しているに対して, 成原等 ${ }^{3)}$ の方法では超過継続 時間一風速比の関係がモデル化されている。

図 3 に示寸風速比一時間の関係を地点別に比較した場合, 南西側 から北東側になるにつれて時間に対して風速比が大きく低減する傾 向にある. また, 係数 $C_{1} \sim C_{4}$ は, 緯度が高くなると大きくなる傾 向がある. これらは, 九州以北では, 台風の移動方向がこの方向と 概ね一致すること, 加えて北上するに従って台風の移動速度が速く なる傾向にあることに関連していると考えられる.

この傾向を踏まえ, 概ね日本全国に渡っての係数を簡易に評価す るため, 緯度をパラメータとし, 式(20)〜(23)によって係数 $C_{1} \sim C_{4}$ を近似する. 図 4 に図 1 に示した全 29 地点の結果を用いて近似した 結果を示す.

$$
\begin{aligned}
& C_{1}=\min \left(-0.532+0.0192 \theta_{N}, 0.217\right) \\
& C_{2}=\min \left(-0.444+0.0210 \theta_{N}, 0.375\right) \\
& C_{3}=\min \left(-0.0565+0.00201 \theta_{N}, 0.0199\right) \\
& C_{4}=\min \left(-0.196+0.00870 \theta_{N}, 0.135\right) \\
& \text { ここに, } \quad \theta_{N} \text { は緯度 }\left({ }^{\circ}\right) \text { である. }
\end{aligned}
$$

図 4 に示すように式(20)〜(23)は, 台風シミュレーション結果を式 (18)および式(19)で直接近似して得られる $C_{1} \sim C_{4}$ に良く対応して いる. 因みに, 風速比の時間变化は, $C_{1} \sim C_{4}$ および時間に関する べき数に比較的鈍感であり, 図 4 に示される近似の程度で十分精度 良く風速比一時間関係を表わせることを確認している.
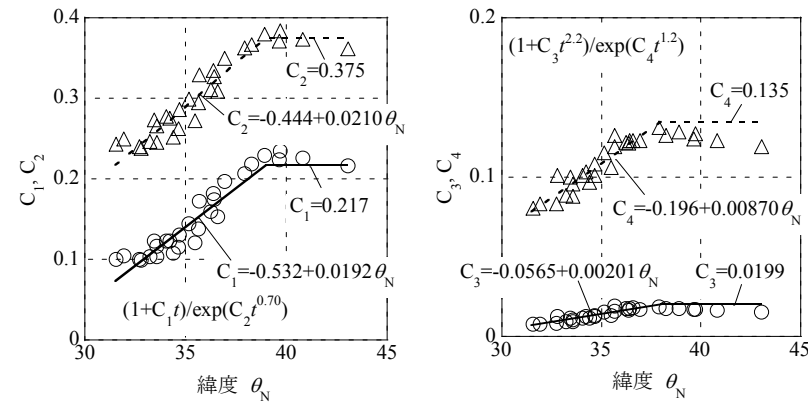

図 4 風速比一時間関係を表わす係数

\section{4. 累積作用時間の算定例と簡易評価方法の有効性}

ここでは, 照查期間 $N$ を 100 年および 250 年として照查期間中の 累積作用時間の算定例を示し, 台風シミュレーション結果に基づい て算定した累積作用時間と比較することで, 提案法の有効性を示す.

\section{1 算定条件の概要}

簡易評価方法においては，まず，地点毎に上位 $N$ 個の経験的再現 期間を式(17)で, 暴風の最大風速を荷重指針式(4)により求める. 続 いて, 各暴風の風速の時間変化を, 安全側の評価となる式(18), 式 
(20)および式(21)を用いて算定する. なお，松井等 ${ }^{10)}$ の提案する等 価継続時間の考え方から判断すると, 最大風速の $60 \%$ 以下となる 12 時間以降の評価精度は, 累積疲労損傷度の評価精度への影響は小さ く, 式(18), 式(20)および式(21)を用いても，式(19)，式(22)および式 (23)を用いてもその差異は小さい

台風シミュレーションでは, 先に求めた各地点のシミュレーショ ン結果を用いる. ただし, 照查期間 100 年の場合には最大風速の再 現期間が 200 年以下， 照查期間 250 年の場合には再現期間が 500 年以下である暴風のみを対象とする。 また，照査期間 100 年の場合 には 500 組，照查期間 250 年の場合には 200 組算定し，それらの平 均值に加えて, 松井等 ${ }^{10)}$ が提案する疲労損傷評価において $m_{s} n_{d}=9$ として等価継続時間が最大となる 1 組，および最小となる 1 組を抽 出する.

作用時間は風速の時間変化が得られた後, $1 \mathrm{~m} / \mathrm{s}$ 毎に風速の個数を 数え, 得られた個数を 10 倍することで分単位の作用時間に換算する

\section{2 累積作用時間の算定結果}

鹿児島, 名古屋, 水戸および仙台を事例に, 各風速の累積作用時 間を図 5 に示す.

いずれの地点においても，照查期間に関わらず，簡易評価方法に よる累積作用時間は，台風シミュレーションによる累積作用時間の 平均から等価継続時間が最大となる組の累積作用時間の值を取り, 妥当な值を示している.

照査期間中で最も高い風速における累積作用時間に着目すると， 台風シミュレーションによる平均值および等価継続時間が最小の組 では 10 分に満たない值となっている. 設計との整合性を考えると, 照査期間中で最も高い風速の累積作用時間は, 台風シミュレーショ ンによる平均值で評価すると危険側に評価される可能性があり，注 意が必要である. なお, 簡易評価方法においては, 算定法の性質上, 最も高い風速での累積作用時間が 10 分を下回ることはない。

\section{3 等価継続時間}

算定地点を鹿児島, 福岡. 高知, 鳥取, 名古屋, 金沢, 新潟, 東 京, 水戸, 仙台, 秋田, 青森および札幌の計 13 地点について, $m_{s} n_{d}=9$ として, 最大風速を $U_{500}$ とする暴風 1 つの等価継続時間を図 6 に示 す，同図に示すように，最大風速を $U_{500}$ とする暴風の等価継続時間 は，簡易評価方法では 50 分〜 70 分，台風シミュレーションでは 30 分〜45 分であり，簡易評価方法の方が安全側の評価となっている. また，東京における等価継続時間が，簡易評価方法では 59 分，台風 シミュレーションでは 36 分であることと, 松井等 ${ }^{10)}$ が試算した「観 測記録より合成した風速記録(羽田, 最大風速: $42.0 \mathrm{~m} / \mathrm{s}) 」$ 」等価継続 時間 49 分とを比較すると,簡易評価方法による等価継続時間はやや 長めで, 安全側の評価となっている.

図 7 に照査期間 100 年および 250 年の場合の等価継続時間を示す. 同図に示すように, 簡易評価方法による等価継続時間は, 台風シミ ユレーションによって得られる最大の等価継続時間と概袮しいか, 大きめの值である。 さらに, 図 7b)の照查期間が図 7a)の 2.5 倍であ ることに着目して, 図 7a)に対する図 7b)の等価継続時間の倍率を比 較すると，簡易評価方法による等価継続時間は 2.5 倍よりやや大き めであるに対し，台風シミュレーションによる最大の等価継続時間 は 2.5 倍より小さめの傾向にある. 照査期間が 250 年を超えるよう な場合には，簡易評価方法による累積作用時間は過大となることが
予想される.
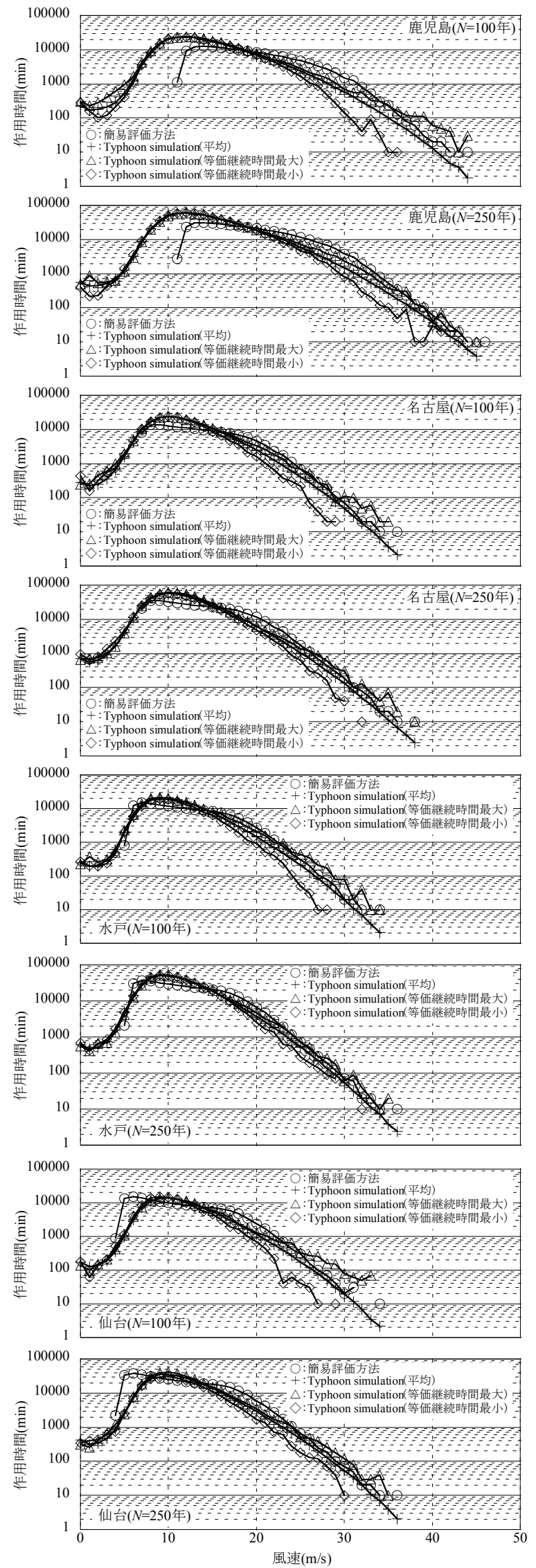

図 5 風速の累積作用時間の算定例 


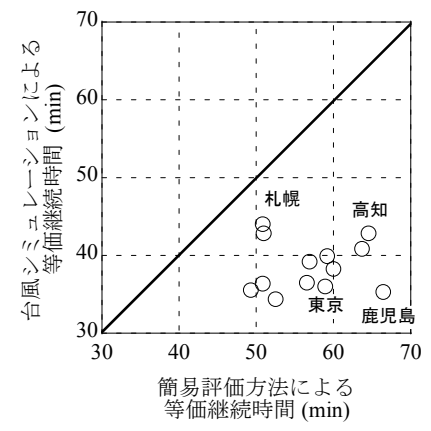

図 6 最大風速を $U_{500}$ とする暴風の等価継続時間

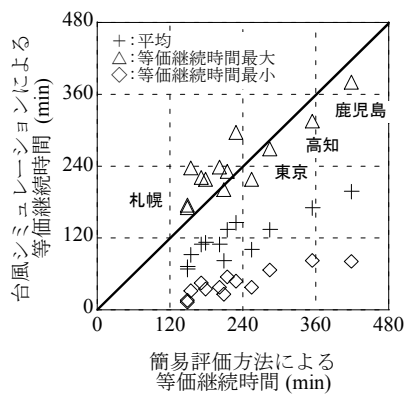

a) $N=100$ 年

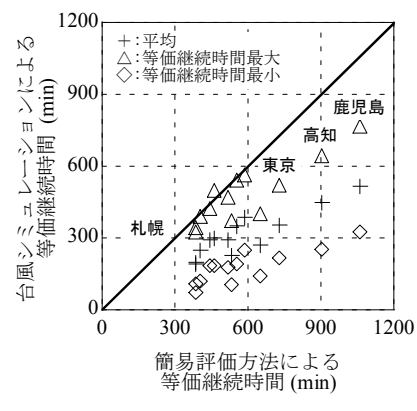

b) $N=250$ 年

\section{図 7 照查期間と等価継続時間}

図 8 に図 6 に示した各照查期間における暴風の等価継続時間を図 7 の最大風速を $U_{500}$ とする暴風の等価継続時間で除した值(以降,

$U_{500}$ 暴風への換算個数と呼ぶ)を示す. 同図に示すように換算個数 は, 照查期間 100 年の場合で $3 \sim 12$ 個, 照査期間 250 年で $7 \sim 22$ 個 で，南側程大きい傾向にある.
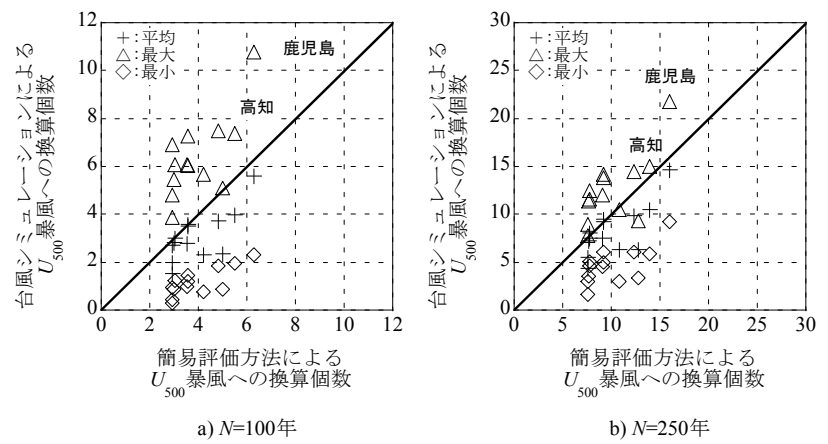

b) $N=250$ 年

\section{図 8 照査期間と $U_{500}$ 暴風への換算個数}

\section{5. まとめ}

ここでの検討と提案を事例に適用寸ることで解ったことをまとめ ると次のようになる.

(1) 九州以北においての年平均の台風数は $0.5 \sim 2.3$ 程度の值で, 台 風以外の暴風を含めると年平均の暴風数は 1 を超えると考えら れる.

(2) 修正 Jansen \& Frank 法によって算定した経験的再現期間を荷重 指針に代入して照査期間 $N$ 年における暴風の最大風速を求め る方法を示した．この方法によって算定される上位 $N$ 個の暴 風の経験的再現期間および最大風速は, 年平均の暴風数が 1 以
上であれば，年平均の暴風数に依存しない.

(3) 松井等 ${ }^{10)}$ の提案する等価継続時間の考え方から, 照査期間 $N$ が 250 年以内の場合は，上位 $N$ 個の最大風速がある程度の精 度で予測できれば，累積疲労損傷評価には十分と考えられる。

(4) 提案する暴風の時間変化のモデル式(18)〜式(23)は, 伊豆諸島, 薩南諸島, 大東諸島, 先島諸島および小笠原諸島を除く日本全 土に渡って適用でき，簡易評価方法として有効である.

(5) 簡易評価方法で算定される暴風の累積作用時間は, 台風シミュ レーションの平均值から最大值程度の值となり, 安全側の結果 を与え，有効である.

(6) 台風シミュレーションによる累積作用時間の平均值は, 高風速 域でやや危険側の值となる場合がある.

（7）照查期間が 250 年を超える場合には，簡易評価手法による累積 作用時間は過大となる可能性がある。

\section{6. おわりに}

本研究は，神奈川大学大熊武司教授，(株)泉創建エンジニアリン グ，(株)日建設計および東京理科大学北村春幸研究室による新耐風 設計法研究会ならびに(社)日本免震構造協会 耐風設計部会(主查 大熊武司)での議論を経たものである.ここに記して謝意を表します.

\section{参考文献}

1) 安井八紀, 大熊武司, 吉江慶祐, 鶴見俊雄 : 供用期間における暴風の累積 作用時間の簡易評価方法 その 1 , その 2, 日本建築学会関東支部研究報 告集 I, pp.421 428，2012

2) 大熊武司, 中込忠男, 丸川比佐夫 : 強風による鋼構造骨組の累積疲労損傷 その 1 , その 2 , 日本建築学会大会学術講演梗概集, pp.75 78, 1988

3) 成原弘之, 泉満, 浅見豊: 風荷重に対する高層鋼構造骨組の疲労設計, 日 本建築学会構造系論文集，第 465 号, pp.129 137, 1994.11

4) 安井八紀, 大熊武司, 廣川雅一, 吉江慶祐，丸川比佐夫 : 高層建築物の疲 労損傷評価に与える強風特性のモデル化の影響に関する研究, その 1 強 風特性のモデル化, 日本建築学会大会学術講演梗概集, pp.185〜186, 2001.9

5) 日本建築学会 : 風と地震による繰返し荷重効果と疲労損傷, シンポジウム 資料， 2003

6) 安井八紀, 大熊武司, 吉江慶祐, 片桐純治, 廣川雅一 : モンテカルロ法を 用いた台風シミュレーションに関する研究, 第 16 回風工学シンポジウム, pp. 441〜446, 2000

7) 山口敦, メルヴィン・ブランコ・ソロモン, 石原孟 : 極值風速予測のため の風速の平均化時間に関する研究, 第 33 回風力エネルギー利用シンポジ ウム, pp.171-174, 2011

8) 藤井健, 光田寧 : 台風による強風の出現確率の予測について, 一海上風の 予測一，自然災害科学，J.JSNDS 11-3，pp.125-145，1992

9) 松井正宏, 孟岩, 日比一喜 : 台風シミュレーションによる年最大風速の推 定, 実測に含まれる不規則変動を考慮した最大風速の予測手法, 第 14 回 風工学シンポジウム pp.97-102, 1996

10) 松井正宏, 大熊武司, 田村幸雄, 飯場正紀, 竹中康雄, 吉江慶祐 : 而風設 計で累積的荷重効果を評価するための強風イベントの等価継続時間, 日本 建築学会大会学術講演梗概集 B, pp.85 86, 2011.8

[2012 年 5 月 25 日原稿受理 2012 年 9 月 28 日採用決定］ 